\title{
Ideogram, kryptogram, miniature og interlineatur
}

\author{
Om Robert Walsers „Mikrogramme“ og \\ kryptoæstetiske former til en „Kleinprosa”
}

\section{JAN BÄCKLUND}

Skriveren, en nu uddød race, som efter bogtrykkerkunsten og senere skrivemaskinen mere og mere blev fortrængt til kontorets og det bureaugrafiske rums bageste, støvede regioner, oplevede sine velmagtsdage i middelalderens og gotikkens skriptorier, som håndværkskyndig kopist af bøger, med en stilbevidsthed og en æstetisk sans som på ingen måde stod i skyggen af samtidens illuminatører, altermalere, stenhuggere eller bogbindere. For en moderne skriver altså en trist melankolsk og selvudslettende historie. Denne triste historie skinner også igennem i Robert Walsers egenhændige levnedsbeskrivelse som han forfattede til en publikation for „Lesezirkels Hottingen" i 1920:

[...] arbejdede snart $i$ forsikrings-, snart i bankvæsenet, boede såvel i Außersihl som på Zürichberg og skrev digte, hvortil er at sige, at han ikke gjorde dette ved siden af, men til disse formål hver gang måtte gøre sig arbejdsløs, hvilket åbenbart skete i den tro, at kunst var noget stort. Digtning var for ham næsten hellig. For mange må det forekomme overdrevent [...] (Fröhlich/H., s. 189).

Kunsten var noget stort; digtningen hellig. Bureaugrafisk arbejde i forsikrings- og bankkontorer er for de små kunstnere, håndværkeren, for kopisten og for skriveren. Skrivningen forholder sig $i$ 
en sådan fantasmatik med respekt for kunsten og poesien, og det er for mig at se ikke usandsynligt at denne fantasmatik spiller en central rolle i Walsers opfattelse af "Kleinprosa“; dvs. en prosa som ikke bare er kort, men som frem for alt er lille, klein, i alle ordets betydninger; altså ikke kortprosa, men småprosa, ubetydelig prosa, prosaisk, modsat poetisk. Denne modsætning finder vi allerede i et af Walsers tidlige arbejder, Fritz Kochers Aufsätze, hvor netop skoleelevens stileskrivning danner ramme for de små beretninger. I stilen „Freithema" beklager eleven sig over lærerens manglende styring med følgende indledende begrundelse:

Denne gang, sagde læreren, må I skrive lige hvad der falder jer ind. Helt ærligt, der falder ikke mig noget ind. Jeg elsker ikke denne form for frihed. Jeg er gerne bundet af et foreskrevet stof. Jeg er for doven til at udtænke noget. Og hvad skulle det også være? Jeg skriver lige gerne om alt. Det pirrer mig ikke at søge efter et bestemt stof, men derimod at udsøge sig fine, smukke ord. Jeg kan af én ide skabe ti, ja hundrede ideer, men jeg kan ikke komme på nogen grundidé. Hvad ved jeg, jeg skriver, fordi jeg synes det er kønt at fylde linierne ud med sirlige bogstaver.

Walsers placering af fortællerjeget i Fritz Kochers Aufsätze - og i Walsers tilfælde må man tilføje, af ham selv - på skolebænken, skrivende stile til læreren/læseren, lector, leder os temmelig naturligt til at se på denne som en kommentar til forfatteren og forfatterrollen. Walser ville ikke være en forfatter som deklamerer, heller ikke en forfatter der, som Peter Altenberg, skrev og konverserede, drak og skrev om dette og hint i det litterære miljø; han ville heller ikke skrive romantisk, på kvistværelset med tuberkulose, nej, Walser ville skrive på skolebænken, i et færdiglinieret skolehæfte. Set fra et historisk perspektiv ville han placere sig $i$ et middelalderens skriptorium.

Fritz Kochers Aufsätze skal nu heller ikke være en forfatters tekster; de skal i stedet være bundne opgaver givet af en højere og kyndigere instans, læreren som retter stilene. Stilene er, skulle man kunne hævde i dette perspektiv, lige så bundne som de pergamentark som middelalderens skriver skrev på, ikke sine egne bøger, men afskrifter af andres. Inden bogtrykkerkunsten slog igennem i slutningen af det 15 . århundrede producerede man 
også tekster i mere end et eksemplar af gangen. I særlig grad gjaldt dette klassikere og tekster som blev anvendt i kloster- og universitetsundervisningen, hvorved man placerede et antal skrivere ved siden af hinanden ved hver sin pult, eller på række på en bænk, i et rum hvor forfatteren (auctor) eller en anden tekstkyndig (lector) forelæste teksten og skriverne nedtegnede det oplæste, og således fik man, efter en kollationering og rettelse af individuelle fejl, et antal bøger ud af samme tekst. Situationen må vi her tænke os ligner til forveksling en scene fra et klasserum. Set i lyset af hele Walsers litterære virksomhed, kan vi også sige, at det som Walser i sin jeg-fornægtende og jeg-udslettende fantasmatik svarer til, er en sådan tilbagevenden fra at have været forfatter og autoritet, auctor, til et ønske om at blive skriver, scriptor, over for en imaginær forelæser, lector.

Walser kaldte aldrig sig selv forfatter, Verfasser, men altid Schriftsteller, og selv om viljen til kancellistil og bureaukratisk sensibilitet er et gennemgående tema i Walsers tekster, sker der i årene fra 1925 til 1927 yderligere en forskydning fra forfatter til skriver. Lige inden Walser blev sindssyg, og den 25. januar lod sig indlægge på anstalten Waldau bei Bern, gennemlevede han en periode af voldsom produktivitet, og det er på det tidspunkt han skrev sin sidste store roman, den såkaldte "Räuber"-roman. Men Der Räuber, som den kom til at hedde, blev sammen med det meste han skrev på den tid skrevet i en ulæselig miniatureskrift. I lang tid anså man denne miniatureskrift for en underlig og grænsepsykotisk kryptoskrift, der ligner de maniske tegninger og tegnophobninger man finder hos schizofrene. De første rapporter der kom om denne skrift blev præsenteret af Carl Seelig i tidsskriftet $D U$, som en "udechiffrerbar hemmelig skrift". Senere viste Jochen Greven i sit forord til „Räuber"-romanen, at der var tale om en slags privat-stenografi, om en miniaturiseret og forkortet udgave af en tysk kurantstil, som Greven benævnte „Mikrogramme". Disse tekster skrev Walser med blyant, og bortset fra "Räuber"-romanen, der blev skrevet på helt hvide ark, blev store dele af disse tekster skrevet i margenen på breve, på kuverter, tidsskriftssider, kalenderblade, formularer, kvitteringer og andet materiale egnet til tilfældige nedskrivninger. 


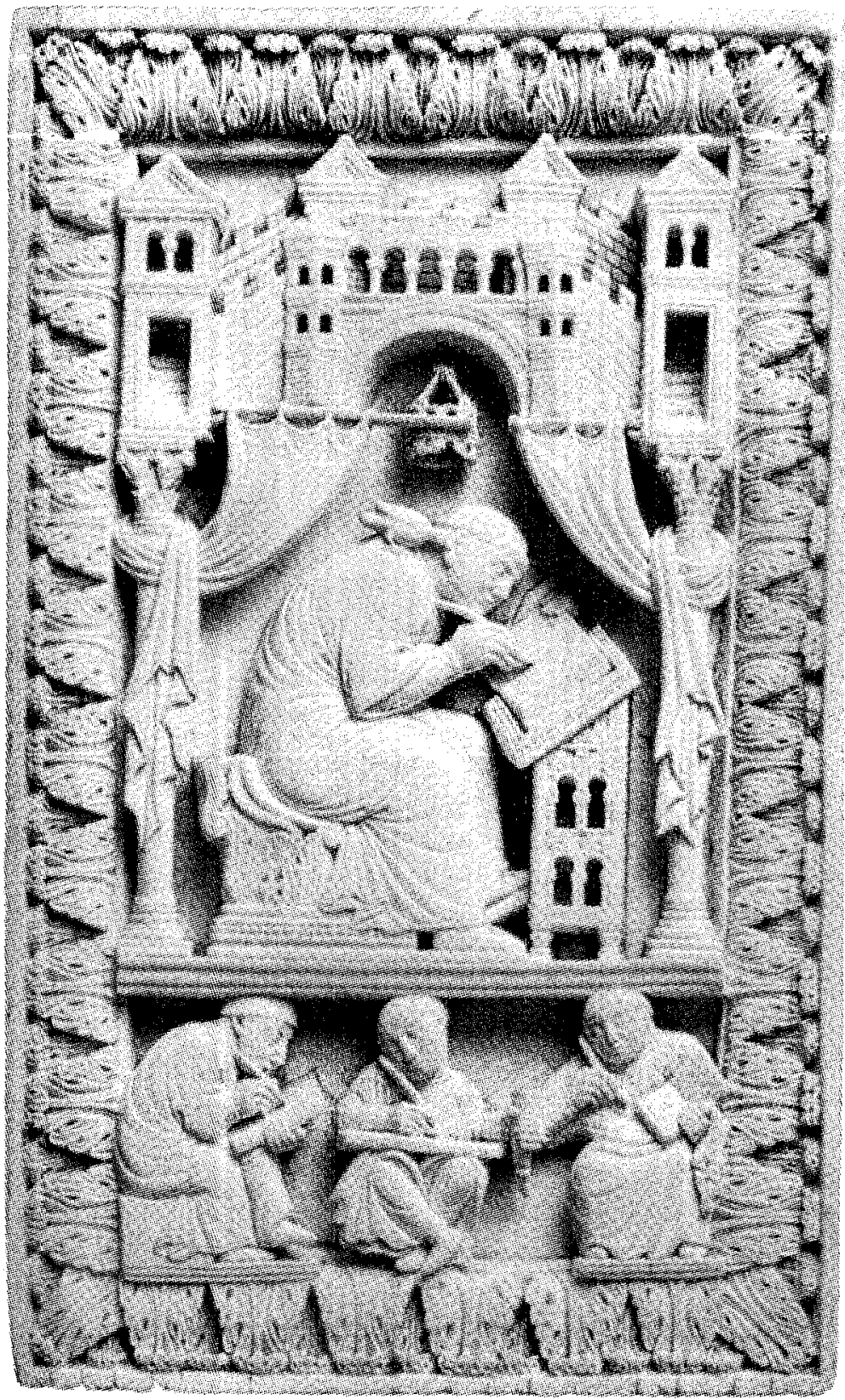


Uden at være i stand til at læse skriften vil jeg alligevel driste mig til at pege på en del skrifthistoriske korrespondenser som synes at passe på Walsers forfatterskab i øvrigt, men nu ikke på en indholdsside, men på en formside.

Miniaturisering. Det der først slår en er naturligvis skriftens format: hvert tegn er skrevet så småt som muligt, ja, det synes som om Walser har lagt en kvalitet $i$ lidenheden, således at skriften - og måske til og med teksten - er bedre med jo mindre tegn den er skrevet, da der åbenbart har ligget en anstrengelse $i$ at skrive teksten så mikroskopisk. Denne skriftform kommer i dette univers af tjenerånder til at svare til Walsers stærkere og stærkere foretrukne "Kleinprosa“. Det gennemgående tema at blive mindre - hvilket jo Kafka i sidste ende har fået just fra Walser, alt denne „Kleinsein“ - får her sit skriftlige korrelat på grafemisk niveau. Nej: tekster bliver ikke bedre jo mindre grafemen er. Vi må ikke forhaste os. Teksten bliver uanseeligere, ubetydeligere; den synes at sige til os: „Du behøver ikke læse mig, det vil anstrenge Dine smukke øjne, den vil tage Din tid. Du vil blive nærsynet" Hvem retter teksten sig så til? Til Ingen? Naturligvis til Gud. Forfatteren, som jo vil forsvinde, ansætter en omhyggelig, tjenstvillig, uudtræettelig og samvittighedsfuld skriver, som med diskrete tegn på uanseelige underlag meddeler Ingen Alt, ganske som de tekster der af lige så tjenstvillige skrivere prentes ned på riskorn eller i en nøddeskal. Beskedenhed er - som altid - naturligvis falsk i dens fortvivlende oprigtighed.

Blive skrift. Når den nysgerrige Jemand bøjer sig over Walsers mikrogrammer genkender han ingenting. Det synes ikke at være en skrift, men en manisk ophobning af ensformige små tegn. At det handler om en tekst, afslører de ikke regelbundne linielængder dog, og at det naturligvis handler om linier i det hele taget, vidner de overstregninger og rettelser som forekommer her og der om. Men endnu kan vi ikke afgøre, ligesom Seelig ikke kunne det i 1957, om det handler om en galnings eller alitterær idiots værk som vil simulere tekst, eller en hemmelig eller ukendt skrift. Ja, for uindviede som os, kunne der lige så godt være tale om japanske, kinesiske eller andre østasiatiske tegn, skrevet i vertikale kolonner, da det er umuligt uden kendskab til skriftsy- 
stemet at afgøre i hvilken retning arkene og lapperne skal vende. $\mathrm{Nu}$ ved vi at teksten er vesterlandsk-horisontal med læseretning fra øverste venstre hjørne til nederste højre, men samtidig er den vesterlandske tekst blevet en orientaloid skrift, ligesom den tjenende ånds stræben for Walser var at blive kineser: ikke være kineser, men, som vesterlænding, blive kineser, lige som teksten her synes at ville blive-skrift.

Kryptogram. Man kan ikke læse skrift, kun tekst er læselig. Kryptografier er skriftens ulæseliggørelse af tekst. For så vidt der faktisk findes en tekst bag en hemmelig skrift (hvilket ikke altid er tilfældet, som med den hemmelige skrift i Edgar A. Poe, The Gold-Bug) kendetegnes kryptogrammet af skriftens Janus-hoved. Skriften er, som mange litteraturhistorikere har betegnet Walser, „ein Grenzgänger", en port ligesom romernes Janus, eller en vejsten for vandrere, som grækernes dobbeltansigtede hermer. En grænsegænger er sådan en hermetisk janus-figur. Dette tema er gammelt, og svarer til narrens spejling af ansigtet (munden, øjnene) med røven, det ophøjede med det lave og neddrige, det store med det små, læreren og eleven, herskeren med tjeneren. Hemmelighederne er også dobbelttydige, ustabile, de slår hurtigt om i deres modsætning "når de svage tror de er de stærke". De er dobbelttydige og ustabile og gør skrifttegn til billedtegn. Skriften fører teksten til et billedets usikkerhedsrum, ligesom de tegn og betydninger soin i miniatureform befolker Gianfranco Baruchellos malerier; små janus'er, som Lyotard - tror jeg indsigtsfuldt - gør en tand mere obskøne: „Hvert monogram [...] er en lille dør, som åbner og lukker sig om det ubestemte. En lille Janus, en lille anus":

Skriptoriets lænke. Fanger skriver sandheder med småt (løgne ridses ind i væggen, fx antallet af resterende dage, kærlighedsforklaringer). De har mange hemmeligheder og lidt plads. De skriver ligeledes på hvad de får fat på. Fængslet i Bastillen skrev markis de Sade sin 120 journées de Sodome i begyndelsen med en rimelig lille skrift, men $i$ takt med at skrivematerialet begyndte at slippe op, udviklede han mere og mere en ulæselig miniaturiseret skrift. Sade skrev på $12 \mathrm{~cm}$ brede ark, som han for portabilitetens skyld limede sammen til en rulle, hvorefter han skrev videre 
på rullens bagside, som i færdig længde kom til at måle 12 meter. En anden grim og liderlig galning, Aleister Crowley, påstår VilaMatas - naturligvis uden nogen som helst grund, men det vedkommer ikke her -, ",havde en ekstremt lille håndskrift. Det lykkedes ham at klemme samtlige ord ind på bagsiden af et fotografi fra Prag og opfyldte således den gamle shandydrøm om en mikroskopisk skrift" (Vila-Matas, s. 101).

Blyant. Walsers mikrogram er givetvis skrevet med blyant, eftersom blyant er udviskelig, ubestandig; blyant anvendes til tilfældige og upålidelige dokumenter eller af ubestandige og svage forfattere, helt ligesom de ubestandige og ubetydelige underlag som Walser forfattede på. Tuschen giver en kraftfuld og dynamisk dybsort form, skrivemaskinen på samme måde en bestemt og regelbunden normeret skrifttype som både trænger ind, presser ned, i underlaget. Modsat disse skriftmedier synes den velformede blyant ligesom at afgive æteriske gråagtige støvkorn, der hæfter sig løst på den kornede papirsoverflade, skriften bliver skrøbelig og - med Duchamps ord - en ultra-tynd hinde på papiret; den fremtræder i forstørrelse som gennemskinneligt affald, som var teksten malet eller tegnet på underlaget. Ultratynd, infra-mince, var for Duchamp et bærbarhedskriterium, en bagage-fysik, „Bestem forskellen mellem omfanget af luft som fortrænges af en ren skjorte (strøget og folieret) og af samme skjorte når den er beskidt." Dette giver for os følgende algebraiske relation:

Skjorte

$$
\text { Smuds }
$$

Snavsetøj

Papir

\section{$\overline{\text { Blyant }}=$}

\section{Kladde}

Abbreviaturen. De bedste skrivere, og de med den største status, skrev bibler, officielle bekendtgørelser fra paver og konger, pragthåndskrifter, livres $d^{\prime}$ 'heures, kronikker, bestiarier, livres de chasses og andet storslået. Disse hørte dog til undtagelsen. Eftersom pergament og papir var dyre luksusvarer, og langt det dyreste materiale i middelalderens bogproduktion, udvikledes fra antikke tider forskellige systemer for kortskrift, brachygrafi, 


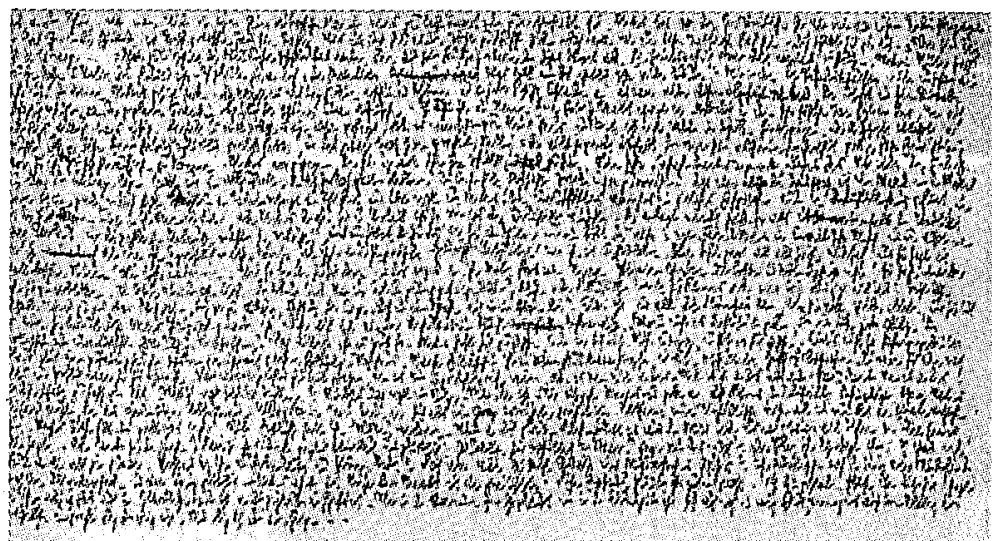

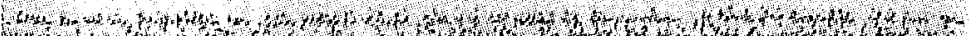

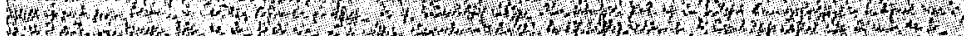

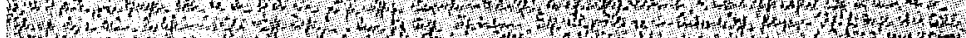

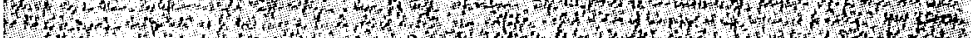

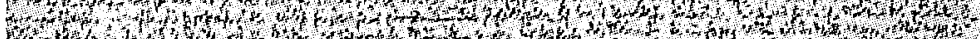

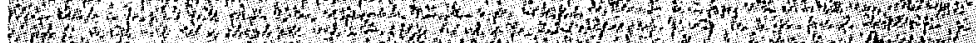

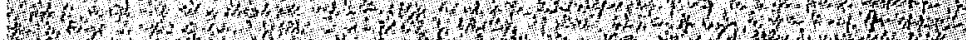

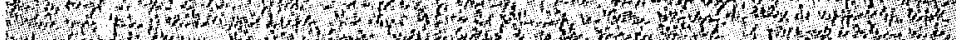

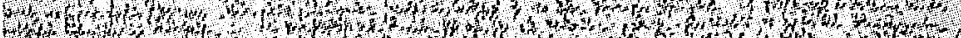

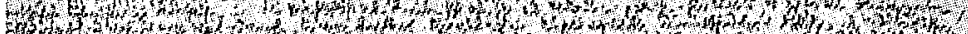

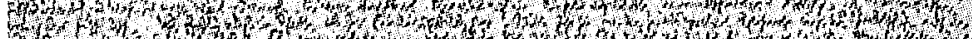

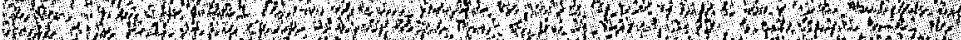

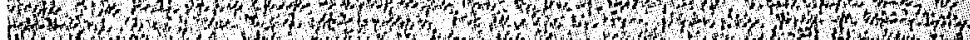

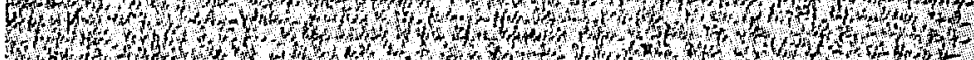

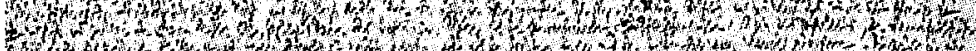

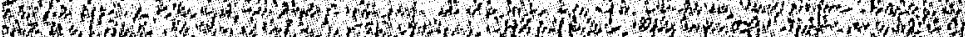

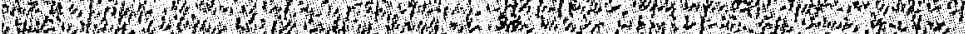

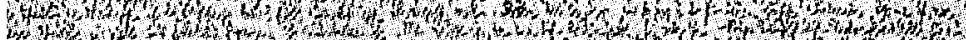

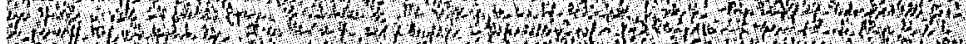

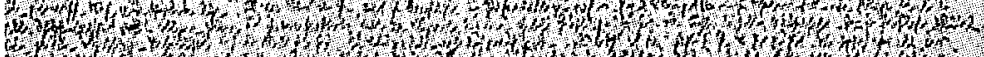

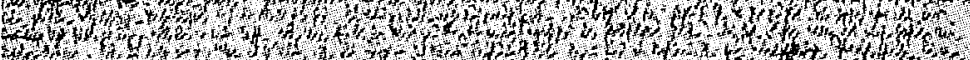

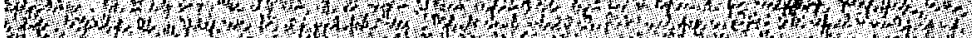

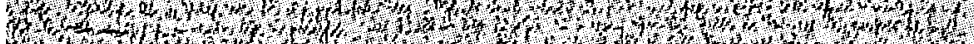

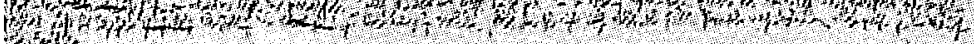

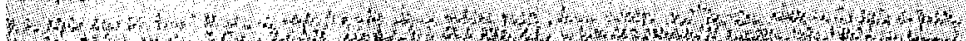

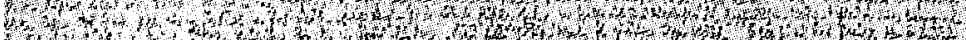

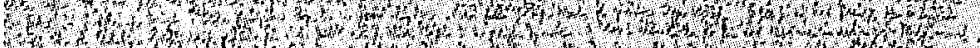

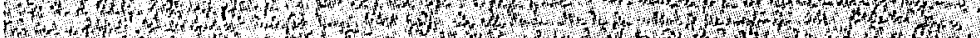

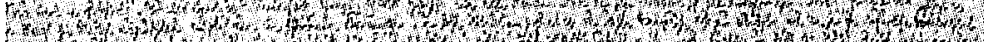

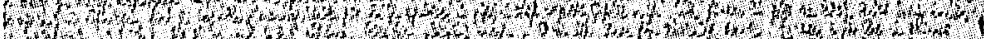

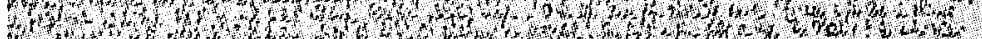
m

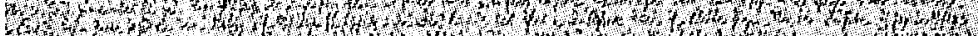

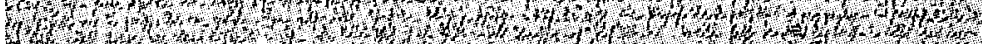

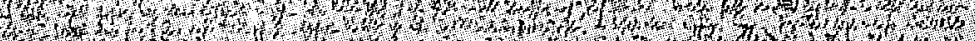

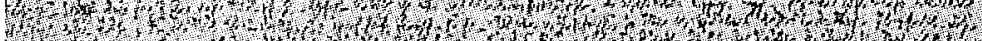

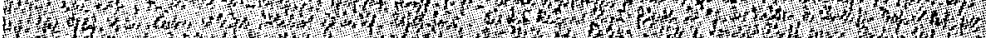

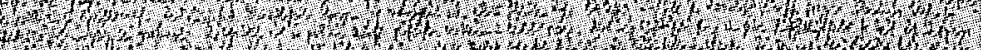

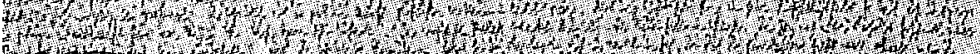

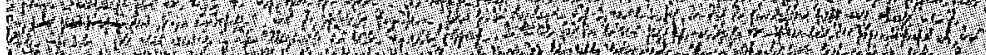
Wr H.

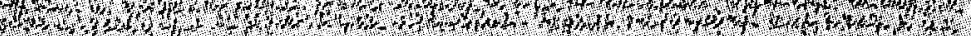


det er derfor ikke svært at se, hvorledes en marginalskriver, i Walsers betydning, må blive „ein Grenzgänger".

Monogrammer. I middelalderens manuskript befolkes marginalen af næsten-billeder, af ornamentale linier, figurer eller mønstre. De er knyttede til teksten uden at have noget med teksten at gøre, de har med skriften at gøre, de hænger så at sige sammen med skriftens hemmelige side, med grafemen. En gotisk skrift får gotiske marginaltegninger, et renæssance-manuskript får renæssance-ornament. Disse kan karakteriseres som skriftens „hændelser", små dramaer som udspiller sig i tekstens udkant. Lyotard definerer disse som udkrystalliserede små hændelser, og han citerer her Baruchello, som selv tydeligt har beskrevet sine malerier, eller måske rettere: billeder, som „ikke-kommunikerbare spøgelser". Baruchello siger selv videre, at de er "flydende tegninger mellem forskellige erfaringer" og "uforlignelige modeller af mulige empiriske situationer". Disse monogrammer handler ifølge Lyotard ikke om symboler eller begreber, men derimod „udgør [de] lagre af narrativ energi: Små fabuleringsmødre", og skal således ikke genfindes eller genfortælles, men må selv skabes og udvikles. På blad $7 \mathrm{i}$ Robert Walsers manuskript til romanen Geschwister Tanner (1907) genfinder vi disse "fabuleringsmødre", og efter min mening af udsøgt kvalitet, som en grafisk hændelse fuldstændig svarende til den fine sirlighed og æstetiske klarhed som kendetegner Robert Walsers tekster. Klarheden ligger, ifølge Lyotard, i at gøre et godt monogram. Lignelsen han tager i brug er denne: „Mesteren giver ham et slag med stokken. Eller bøvser. Den kyniske mester prutter. G. B. tier".

I 1948 afslutter en anonym læge en længere redegørelse om Walsers tilstand, som, havde det ikke handlet om et vesterlandsk sindssygehospital, kunne ligne den zenbuddhistiske modalitet som Lyotard ser hos Baruchello:

Er nu blevet lidt ivrig, taler temmelig spontant løs, beretter dog sagligt, på en eller anden måde uberørt, som om det hele slet ikke vedkommer ham, har i det hele taget noget automatagtigt over sig. Ansigtet er lidt maskeagtigt, holdningen stiv og temmelig stereotyp. Står altid samme sted, hændeme foldet på ryggen, blikket lidt tomt og rettet stift ligeud, 
"kunsten at skrive kortfattet", som Capelli i sit i lang tid klassiske Lexicon Abbreviaturarum definerer det, fra antikkens tironske noter (hvorfra vi stadig har "\&"), og som i hele middelalderen udvikler et kompliceret og intrikat system for skriftlige forkortelser, abbreviaturer. Håndskrifter som anvendte dette system for abbreviatur kaldtes kursiv. Man brugte dem i forbindelse med skrifter som ikke gjorde krav på større værdi, og udgjorde typisk afskrifter af andre håndskrifter til privat læsning eller brug. Kortformer, bærbarheder og miniaturer står i et lige så uafklaret som usvigeligt forhold til mystifikationer og hemmeligheder, og naturligvis er det også en sådan ny form for abbreviatur vi har at gøre med hos Walsers mikrogram. Fröhlich/Hamm kalder Walsers miniatureskrift for "en art privat-stenografi"; og stenografi er er moderne aftapning af disse middelalderlige abbreviaturer, som kommer fra stenos, trang, snæver, hvilket på sin side står i etymologisk forbindelse med steganografi (fra steganos, tæt, tækkende), hvilket var en ældre betegnelse for hemmelig skrift.

Marginalia. Specielt for marginalskrifter blev kursiven og dens flittige anvendelse af abbreviaturen effektiv, og i middelalderen udvikledes en hel genre af miniaturiserede og stærkt abbriverede kommentarskrifter i margenerne og mellem linierne (interlineaturen) i håndskrifter, og med hele siden fyldt ud af sådanne kommentarer indeholdt- disse marginalia med lethed 50 eller 100 gange større tekstmængde end brødteksten. Walser havde ingen brødtekst at kommentere. Ja, sådan ser dẹt umiddelbart ud, men ikke desto mindre skrev han altid på lapper, kvitteringer eller andre brugte papirvarer, hvor den trykte eller skrevne trivialtekst gives funktion af brødtekst. En triviel funktion, ja, men stadigvæk brødtekst. Det er således alle disse verdens trivielle tekstudslip som Walser iscenesætter som brødtekst for sine marginalia; ikke den litterære verdens Store Værk, eller Ærefulde Poesier, men den bureaugrafiske verdens trivielle grafem. Tekstens længde hos disse marginalskrifter synes for Walser at være uvedkommende, og "Räuber"-romanen er jo en tekst af anseelig længde, men det er dens status som marginalia som først og fremmest gør skriften til Kleinprosa, til marginalskrift. Marginal kommer fra det latinske margos, hvilket betyder kant, grænse, og 
omgiver sig ikke med nogen. Udadtil høflig, korrekt, vækker aldrig nogen anstød, fuldstændig uden at stille krav, udfører villigt ethvert stykkearbejde, der tildeles ham. Gør bordet rent efter maden, laver altid gerne papirsposer. I de ledige stunder bladrer han som altid i gamle billedblade. Ønsker sig ingen bøger, ingen aviser. Afviser som altid brysk enhver begunstigelse. Fysiske sundhedsstilstand ret god, sågar bedre end for to tre år siden, ingen former for beklagelser (Fröhlich/H. s. 297).

Enrique Vila-Matas beretter i sin Historia abreviada de la literatura portátil - bestemt i skønlitterær form, men ikke uden æstetikhistorisk tyngde - om store dele af den litterære og kunstneriske avantgarde netop som en hemmelig sammensværgelse af miniaturisører og vandrere, centreret omkring små kufferter, ekstreme seksualiteter, opfindelsesrigdom, fravær af storslåede forsæt, frækhed samt uudtrættelige rastløsheder. I middelalderen installeredes skriveren sædvanligvis i kælderen, hvor han nærmest -i det mindste ideelt og fantasmatisk set - blev lænket fast til en pult, men hvor den bog som skulle afskrives var fastlænket og hvor værktøjet ligeledes var fastlænket. I denne kælder, møbleret med skrivepulter og bogskabe, smykket med kæder, bånd, båndspænder, forsynet med perforeret dyrehud, i mørke, fugt og støv, må vi forestille os middelalderens nærsynede bognarre og kontorslaver indespærret, ikke sjældent siddende i flere år med samme bog, sirligt og med stor kunstfærdighed tegnende deres bogstaver, og, hvis et anakronistisk udtryk må være mig tilladt, iscenesatte en ganske unik masochistisk atmosfære, ikke langt fra Walsers - tror jeg - store litterære forbillede, som, den i århundredeskiftet så fejrede, forfatter Leopold von Sacher-Masoch, optegnede i mange af sine romaner; eller, som siden Kafka videreførte fra sit forbillede, netop "Robert Walser, til det i Centraleuropa så udbredte brune, støvede og monotone „forsikrings- og bankkontor".

Det har formentlig ikke noget på sig, men margos, hvilket kunne være et græsk ophav til det latinske margo, betyder slet ikke grænse, men rasende, lidenskab og galskab; men det er ikke umuligt at dette raseri, denne liderlighed og galskab lige præcis er hemmeligheden som skal dølges, formindskes, marginalise- 
res, skrives mellem linierne, på allerede brugte papirslapper: smaiprosaens hemmelighed.

\section{På dansk ved Peter Nielsen}

\section{Litteratur:}

Adriano Cappelli: Lexicon Abbreviaturarum ..., Leipzig: J. J. Weber, 1901. Duchamp, Marcel: Marchand du sel: Ecrits de Marcel Duchamp, ed. Michel Sanouillet, Paris: Terrain vague, 1959.

Fröhlich, Elio und Peter Hamm (Hrsg.): Robert Walser. Leben und Werk in Daten und Bildern. Mit einem Essay von Peter Hamm. Frankfurt a.M.: Insel 1980.

Jackson, Donald: The Story of Writing, London: Shuckburgh Reynolds Ltd on behalf of Parker Pen Company, 1981.

Lyotard, Jean-François: "Det hemmeliges maleri i den postmoderne tidsalder, Baruchello", Det lokale og det universelle, red. af Stig Brøgger, Else Marie Bukdahl og Hein Heinsen, København: Det kgl. danske Kunstakademi, 1986, s. 35-47. Da. overs. Carsten Juhl fra: "La peinture du secret à l'ère postmoderne. Baruchello", Traverses, no. 30-31, Paris 1984.

Lettres, Signes, Ecritures. Udstillingskatalog, Malmö: Malmö Konsthall, 1978.

Vila-Matas, Enrique: Kortfattad inledning till den bärbara litteraturen, Malmö: Interculture, 1988. Sv. overs. Miguel Ibáñez fra Historia abreviada de la literatura portátil (1985).

Walser, Robert: Fritz Kocher's Aufsätze, Leipzig: Insel, 1995 (1904).

Robert Walser aus dem Bleistiftgebiet, Band 3, "Räuber"-Roman und "Felix"-Szenen. Im Auftrag des Robert Walser-Archivs der Carl SeeligStiftung/Zürich neu entziffert und herausgegeben von Bernhard Echte und Werner Morlang, Frankfurt 1986. 